\title{
The Behavior of Money and Other Economic Variables: Two Natural Experiments
}

James R. Lothian

Fordham University

Cornelia H, McCarthy

Fordham University

Follow this and additional works at: https://fordham.bepress.com/crif_working_papers

Part of the Finance and Financial Management Commons

\section{Recommended Citation}

Lothian, James R. and McCarthy, Cornelia H, "The Behavior of Money and Other Economic Variables: Two Natural Experiments" (2003). CRIF Working Paper series. 11.

https://fordham.bepress.com/crif_working_papers/11 
The Behavior of Money and Other Economic Variables: Two Natural Experiments

James R. Lothian

and

Cornelia H. McCarthy*

* Schools of Business, Fordham University. 113 West $60^{\text {th }}$ Street, New York, NY 10023, USA. Lothian: tel. 1212 636-6147, email lothian@fordham.edu; McCarthy: tel. 1212 636-6139, email comccarthy@fordham.edu. We would like to thank John Devereux, Keith Cuthbertson, Gerald P. Dwyer, Rik Hafer, Peter N. Ireland, Ella Kavanagh, Mark P. Taylor, Daniel Thornton, Liuren Wu and participants in the Fordham Center for Research in International Finance Workshop and the Irish Macro-Finance Symposium for their comments on an earlier draft of this paper. The usual caveat applies. 


\section{The Behavior of Money and Other Economic Variables: Two Natural Experiments}

\section{JEL: E5 and F3}

\section{Keywords: Money Behavior, Inflation}

Every once in a great while, history provides us with a natural experiment, an episode in which a major change in a key economic variable occurs that has no direct relation to the contemporaneous behavior of the variables that theory suggests it ought to effect. ${ }^{1}$

A classic example was the currency reform during the U.S. Civil War by the Confederacy in spring 1864. A second was provided by the massive inflow of specie from the New World to Spain in the sixteenth century. In the first of these examples, a rapidly growing money stock suddenly fell and a decline in the price level followed. In the second, a century-long upward movement in price levels occurred throughout most of Europe. The question that researchers addressed in both instances had to do with the links between the monetary changes and the price behavior that followed (Lerner, 1956; Hamilton, 1934).

In this paper, we investigate a similar set of questions using data from two much more recent episodes, both involving changes in the inflation and monetary-policy regimes: the move to floating exchange rates following the breakdown of Bretton Woods in the early 1970s, and the shifts toward less expansive monetary policy that to varying degrees occurred throughout the industrialized world a decade later. In the case of the float, inflation which had been rising since the mid-1960s, surged throughout the industrial world, in some countries like the United Kingdom reaching peaks well into the double digits. Following the shifts to less expansive domestic policy, inflation peaked in most of those same countries and has continued to decline more or less unabated until the current day. John Taylor (2002) in reviewing the monetary history of this era, described it as "the Great Inflation flanked by two periods of relative price stability."

\footnotetext{
${ }^{1}$ See Bernanke (2002) for a discussion of important empirical role that such experiments have played in monetary economics.
} 
The most straightforward, but not at all uncontroversial, explanation of these drastic changes in inflation behavior is in terms of the quantity theory of money. In the simplest quantity theory model, these differences correspond in one-to-one fashion with differences in monetary behavior. According to this explanation, inflation rose on average as monetary policy became more expansive in the United States, the reserve-currency country under the Bretton Woods system and the effects that more expansive policy spilled abroad. Cross-country differences then began to emerge as a result of increased differences among countries in domestic policy goals. The breakdown of Bretton Woods and move to floating exchange rates resulted from, and subsequently accommodated, this difference in policy goals. ${ }^{2}$ Correspondingly, inflation rates both fell and converged internationally in 1984-98 as monetary policies in the various countries became less expansive on average and more closely in sync with one another during the course of this period.

This explanation, however, has been subject to dispute on several scores. From the very outset, many economists have questioned the assertion that the increased rate of inflation post-1973 was primarily the result of shifts in monetary policy goals. The then-reigning and still popular alternative explanation attributed the inflation increase to the first oil-price shock. ${ }^{3}$ The continued high inflation for a decade thereafter, proponents of this view argued further, was due primarily to the second oil-price shock in 1979, and the lower inflation that followed to the absences of such shocks.

A second area of dispute is the behavior of the demand for money following the waves of financial innovations that began around the start of $1980 \mathrm{~s}^{4}$ Indeed, this behavior has seemed so problematic, that a number of papers have appeared in Federal Reserve publications and other research-oriented publications

\footnotetext{
2 See Bordo (1993), Darby, Lothian, et al. (1983), and Meltzer (1991) for discussions of the Bretton Woods period.

${ }^{3}$ Blinder (1982) was an influential proponent of this explanation. Darby (1982) and Gandolfi and Lothian (1983), however, present largely contrary evidence.

${ }^{4}$ Empirical investigations concerned with this issue include Friedman and Kuttner (1992), Estrella and Mishkin (1997) and Carlson, et al. (2000).
} 
with titles ranging from "Is there a Role for Monetary Aggregates in the Conduct of Monetary Policy?" (Estrella and Mishkin, 1997), to "Are Money Growth and Inflation Still Related?" (Dwyer and Hafer, 1999), to "What Remains of Monetarism?" (Hafer, 2001). While the authors of the latter two studies present evidence that is largely favorable to the quantity theory model, Estrella and Mishkin, and others such as Friedman and Kuttner $(1992,1996)$, have been less sanguine. Perhaps more telling in this regard are the actual practices of monetary policy makers. Most industrial country central banks focus exclusively on one or the other short-term interest rate in conducting policy, with little seeming attention to the various monetary aggregates (Borio, 1997). Indeed, the well known "Taylor rule" for the conduct of monetary policy is couched in terms of a short-term interest rate (in the U.S. case, the federal funds rate) rather than money supply or some narrower monetary aggregate such as bank reserves or high-powered money.

A corresponding series of objections has been raised with regard to the monetary model of exchange rates implicit in the quantity theoretic explanation of inflation behavior. In what has become a classic article on the subject, Meese and Rogoff (1983) demonstrated the poor predictive power of the model relative to a naive random-walk forecast. Flood and Rose (1995) reached similar conclusions using quite different methods. They compared the volatilities of nominal exchange rates and the variables that appear as arguments in standard exchange-rate equations -- the "fundamentals." Nominal exchange rate volatility was of course greater under a float than under fixed rates but the volatility of the fundamentals was roughly the same in their data set. Their conclusion was that "the most critical determinants of exchange-rate volatility are not macroeconomic." A related body of literature has raised questions with regard to the insulating properties of floating exchange rates. See, for example, Lastrapes and Koray (1990), Joyce and Kamas (1995) and Wheeler and Pozo (1995).

In the empirical analysis that follows, we investigate the relations between money and prices, real incomes and exchange rates using panel data for 20 OECD countries over the period 1957 to 1998 . In so 
doing, we focus is on the cross-country and cross-regime dimension of these data. ${ }^{5}$ We use data in the form of growth shifts, cross-regime changes in the within-regime average rates of growth of the variables .

We adopt this method of data analysis for several reasons. One, which we already have discussed, is the quasi-controlled experiments to which these changes in the monetary regime give rise. In principle, they should be very nearly exogenous to contemporaneous changes in inflation and the other economic variables of interest. A second is that averaging the data is one way to proxy the long-term equilibria of theory. The recent literature on tests of the neutrality proposition central to such theory stresses the importance of this factor (see, for example, Fisher and Seater, 1993). A third reason has to do with the magnitude of these cross-regime shifts. The differences in average inflation rates across the three regimes account for close to 90 per cent of the movement in that series over this forty-year period. ${ }^{6}$ They, therefore, have been and still are of considerable interest in and of themselves, not just to researchers but also to policy makers and the general public. Finally, focusing on such movements takes us at least part way in solving the signal extraction problem that so often seems to plague empirical investigations of economic data.

Estrella and Mishkin (1997) and Friedman and Schwartz (1991) contain discussions of this problem in the specific context of monetary economics. Estrella and Mishkin point out that one possible reason for their largely negative results may simply be a low signal-to-noise ratio in their data, since their sample is dominated by a period of low variability in the growth rates of both money and the other nominal variables of interest. In such an environment, shocks to velocity, the "noise"in the system, can more easily obscure the monetary effects, the "signals," and thus mask the true relationships between money supply and nominal income and the price level. Friedman and Schwartz (1991, pp.43-45) discuss this problem in the more general context of the errors-in-variables (e.i.v.) model. They suggest that such

5 Earlier studies employing a methodology similar to ours include Duck (1993), Dwyer and Hafer (1999), Lothian (1985), McCandless and Webber (1995), and Schwartz (1973).

${ }^{6}$ See the regression results presented below in Table 1a. 
errors be "interpreted to include all stochastic disturbances affecting the variables under study." They go on to say that in economic investigations, these errors generally have two dimensions, stemming both from the use of imprecise empirical proxies for the variables suggested by theory and from actual errors of measurement in the proxies themselves.

Our use of averages of the underlying data is a traditional method of dealing with errors-invariables (e.i.v.) problems of the sort enumerated by Friedman and Schwartz. The techniques we use help correct for various aspects of this problem. The broader temporal movements upon which we focus are likely to have a higher signal-to-noise ratio than the monthly or quarterly data used in most studies and thus be less subject to the difficulties that Estrella and Mishkin describe. As Coakley, Flood and Taylor (2002) point out taking account of the cross-country variation is likely to help further.

The results we obtain using these procedures, for the most part, are highly positive. The moneyprice relationship that we observe is fully consistent with theory - growth shifts in the nominal stock of money and in the price level are highly correlated and bear a one-to-one relation to one another. Growth shifts in exchange rates are significantly related both to growth shifts in relative price levels and to growth shifts in relative excess supplies of money. The classical neutrality proposition receives positive, though not totally unambiguous, support.

Though considerably better than one would expect on the basis of much of the current literature, these results are not without recent precedent. Studies of the links between money growth and inflation and money growth and nominal income that use longer-period averages of the data, such as Dewald (1998, 2003), Dwyer and Hafer (1999), and McCandless and Weber (1995) and of money demand that use cointegration techniques such as Carlson et al. (2000) all report positive findings. The same is true for studies of exchange rate behavior that use either long historical data sets (e.g., Lothian and Taylor 1996; Alan Taylor, 2002), or long-period averages of (differenced) multi-country panel data (Flood and Taylor, 1996; Lothian, 1997). Perhaps tellingly from the standpoint of the e.i.v. problem, in all of these instances the focus is on long-run behavior and in most of the data sets are characterized by substantial variation in 
the series in question

\section{Industrial Country Inflation in the Post-World War II Period}

In the early post war years, the Bretton Woods Agreement for fixed exchange rates exerted a powerful force on inflation behavior in the countries making up that system. Under the Bretton Woods regime, cross-country inflation differences were non-zero but generally quite small. In the absence of revaluation or devaluation, inflation rates and monetary policies could not wander too far from inflation and monetary policy in the United States, the reserve-currency country. The agreement started to break down when in August 1971, the United States unilaterally floated. The European countries, after futile attempts to maintain some exchange-rate fixity, gave up the ghost a little over a year and a half later and a new era in the behavior of monetary policy and inflation both within and across countries began.

Figures 1 and 2 describe post-World War II inflation experience. Figure 1 presents a time-series plot of the average inflation rate across the 20 countries in our data set and Figure 2 presents a comparable plot of the cross-country standard deviation of those inflation rates. ${ }^{7}$ A visual inspection of the data shows that the Bretton Woods' era was characterized both by moderate rates of inflation and by moderate crosscountry variability. Inflation behavior, however, changed in both respects after 1973. In the early years of the floating exchange rate regime the cross- country average inflation rates were considerably above the average rates during the fixed exchange rate regime and much more disparate across countries. However, high and volatile inflation rates do not continue. Somewhere in the mid-1980s the pattern of inflation changed again, this time characterized by low inflation rates and moderate to low cross-country variability.

\section{I.A. Estimation of a Second Structural Break}

${ }^{7}$ Data in Figure 1 are the annual averages of inflation for the following OECD countries: Australia, Austria, Belgium, Canada, Denmark, Finland, France, Germany, Ireland, Italy, Japan, Netherlands, New Zealand, Norway, Portugal, Spain, Sweden, Switzerland, United Kingdom and the United States. The data in Figure 2 are the crosscountry standard deviations of these annual averages. The source of these data was the IFS on CD-Rom. 
To attach some precision to the dating of these changes in inflation behavior, we ran autoregressions of the form:

$$
X_{t}=b_{1}+b_{2} D 2+b_{3} D 3+b_{4} X_{t-1}+\epsilon_{t}
$$

where $\mathrm{X}$ is either the average cross-country inflation rate or the standard deviation of the cross- country inflation rate, D2 and D3 are zero-one dummy variables, $b_{1}$ through $\mathrm{b}_{4}$ are coefficients to be estimated and $\epsilon_{\mathrm{t}}$ is an error term. We ran these regressions over the period 1957 to 1998 . using both the annual average CPI inflation rates for the 20 OECD countries plotted in Figure 1 and the individual country inflation rates themselves. For comparison purposes, we ran a similar regression for the cross-country standard deviations plotted in Figure 2.

We assume that the breakdown of Bretton Woods agreement in 1973 can be used as the end-date of the first (low-inflation) regime. We therefore created a dummy variable, D2, that took the value of one for the years 1974 to1998 and zero otherwise and let the data inform our choice of the date of the second break. To do so this we created a second dummy, D3, that took the value one for the years 1977 to 1998 and zero otherwise and then went on to create 21 additional versions of this variable, in each instance letting the starting date for the third period begin one year later. We then run the regression for each version of the D3 variable and chose as the second breakpoint the date that minimized the standard error of the regression. The breaks that we identified on the basis of this procedure were 1982-83 for the crosscountry average inflation rate and 1988-89 for the cross-country standard deviation of the inflation rates. The estimates for these dates and corresponding Chow tests are presented in Tables 1a and $1 \mathrm{~b}$.

We used the same procedure for the individual countries' inflation rates. The resulting dates for the beginning of the third period of inflation behavior on a country-by-country basis are presented in Table 2. As the table indicates, these dates differ somewhat among countries, the shifts in the inflation regimes in Japan and the Netherlands coming much earlier than in the other countries and the shift in Australia, 
Sweden and possibly Switzerland, coming much later, though the Swiss finding may be spurious given the low and relatively stable rates of Swiss inflation over most of our sample period. The means and medians of these individual-country figures show breaks occurring a year later than for the average inflation rate 1983-84 versus 1982-83. In the empirical work reported below we used the later of these two breakpoints in computing growth shifts. None of the results we report depend crucially on that choice, however. In additional work not reported here, we obtained virtually identical results using the alternative 1982-83 breakpoint.

\section{Money and Inflation: Theoretical Considerations}

The changes in the inflation regime that we have just described provide us with the two natural experiments to which we alluded at the outset of this paper and which we go on to use in testing alternative explanations of inflation and of macroeconomic behavior more generally.

To formalize the argument and illustrate the potential differences in economic behavior under regimes of fixed and floating exchange rates, let us consider a long-run, two-country quantity theoretic model. A model of this sort underlies the analysis Friedman and Schwartz's (1963) Monetary History as their subsequent discussion (1991) makes clear. It is the basis of the monetary approach to the balance of payments advanced by Harry G. Johnson and others at the end of the 1960s and early 1970s (e.g., Johnson, 1969). Along with its closed-economy analogue it also underlies much other theorizing on the subject of inflation (e.g., Schwartz, 1973).

This two-country world is made up of a small open domestic economy and large reserve-currency country. In the case of the domestic economy, the model takes the form of a demand for money function, a monetary equilibrium condition, and a modified purchasing power parity relation.

We write the demand for money function as:

$$
\mathrm{dm}^{\mathrm{d}}=\mathrm{L}(\mathrm{dy}, \mathrm{di}, \mathrm{u})+\mathrm{dp},
$$


where $\mathrm{dm}^{\mathrm{d}}$ is the percentage rate of growth of the desired quantity of nominal cash balances demanded, dy is the percentage rate of growth of real income, di is the change in the nominal rate of interest, dp is the rate of inflation and $\mathrm{u}$ is a portmanteau variable included to represent other factors such as the degree of financial sophistication and the quality of money. Real income in the long-run context of the model is assumed to be exogenous, determined outside the model in the Walrasian system of equations that describe the myriad individual markets making up the economy. It is, moreover, assumed to be unaffected by changes in monetary growth. Money is "neutral."

The purchasing power parity relation is also written in terms of rates of change and takes the form:

$$
\mathrm{dp}=\mathrm{dp} \mathrm{p}^{\prime}+\mathrm{de}-\mathrm{dq}
$$

where a prime signifies the reserve-currency country, de is the percentage change in the nominal exchange rate, defined as the price in domestic currency of a unit of the reserve currency, and dq is the percentage change in the (equilibrium) real exchange rate. Inclusion of the last term, therefore, allows for the effects of real variables, such as continued differences in productivity growth in the two countries, on the exchange rate. In the fixed exchange rate case, de is zero and if dq is also zero, as it is assumed to be in the strict version of the purchasing power parity hypothesis, dp will equal dp'.

In equilibrium, the growth rate of the nominal quantity of money supplied and the growth rate of the nominal quantity of money demanded also are equal:

$$
\mathrm{dm}=\mathrm{dm}^{\mathrm{d}}
$$

Combining (3) with (1) and recalling the discussion in connection with (2), we get: 


$$
\mathrm{dm}=\mathrm{L}(\mathrm{dy}, \mathrm{di}, \mathrm{u})+\mathrm{dp} \text {. }
$$

The upshot here is that with dp' given, the nominal stock of money in the domestic economy is proximately determined by the quantity of real cash balances demanded.

Monetary growth and inflation in the case of this assumed small domestic economy, therefore, are jointly determined. For the reserve-currency country, in contrast, monetary growth is determined by domestic policy considerations. Given the behavior of the real quantity of money demanded, it in turn determines the rate of inflation both in the reserve-currency country and per the discussion above in the domestic economy too.

Interest rates in this world of long-run equilibrium and fixed exchange rates are assumed to change by the same absolute amount in the domestic economy and in the reserve-currency country. By definition, exchange rates are fixed. If they are expected to remain so, then via uncovered interest-parity, the levels of nominal interest rates in the two countries will be equal. Since actual and anticipated rates of inflation within each country are equal by the assumptions of the model, real interest rates via the Fisher equation will be equal.

In a floating exchange rate world, equations (1), (2), and (3) and the reserve-currency-country analogues of (1) and (3) are combined into a three-equation system in which the rate of change of the exchange rate is determined by the difference in the growth rates of the excess supplies of money (dm - L) in the two countries and each country's inflation rate is determined by growth in its excess supply of money alone.

We can write these equations as:

$$
\begin{aligned}
& d e=d m-L(d y, d i, u)-d m^{\prime}+L^{\prime}\left(d y^{\prime}, d i^{\prime}, u^{\prime}\right), \\
& d p=d m-L(d y, d i, u) \\
& d p^{\prime}=d m^{\prime}-L^{\prime}(d y, d i, u) .
\end{aligned}
$$


Again these are to be viewed as long-run equilibrium equations.

Unlike the fixed-rate case, there is no necessary connection between growth rates of the supply of and the demand for money. Money supply growth in both countries is now determined by domestic considerations. An increase in the growth rate of the demand for money with no change in the growth of supply would result in a decrease in the rate of inflation. Variations in L will impinge on dm only if policymakers choose to stabilize dp.

In further contrast to the situation under fixed exchange rates, nominal interest rates are free to vary among countries. Here uncovered interest parity is consistent with differences in the levels of interest rates equal to the percentage rate of increase of the exchange rate. This independence of nominal interest rates does not correspond, of course, to a similar independence of real interest rates which may be even more harmonized if capital controls imposed under fixed exchange rates have been removed, which as Goldberg, et al. (2003) show, appears to be the case.

The implications of the model are, therefore, straightforward. In the long-run equilibrium world that it describes, the growth in the excess supply of money should bear a one-to-one relationship to inflation and no relationship to real income growth. Qualitatively, the same thing should be true for relative inflation rates and hence by extension relative excess money growth vis-à-vis exchange-rate growth: one-to-one relationships between both nominal variables and the rate of change in the nominal exchange rate and no relationship between either and the rate of change of the real exchange rate.

\section{Empirical Results: Cross-country Relationships}

The data we use to test these propositions are for the same countries and period as the inflation data. For all 20 countries, we have collected annual figures for the period 1957-1998 for high-powered money ("reserve money" in IMF terminology), a broad definition of money, which we label M2 (generally the sum of what the IMF terms "money" and what it terms "quasi-money"), a cost of living index, real and nominal GDP, and U.S. dollar exchange rates. We stop in 1998 because of the introduction of the Euro in 
1999 and resultant change in the Euro-area monetary data. The sources of most of these data again was the International Monetary Fund's International Financial Statistics, both the CDROM and print versions. ${ }^{8}$ For each of the variables of interest we computed average rates of growth for each country for each of the three regimes separately. We then took the first differences of these averages and used the resultant figures - the "growth shifts" - as our basic units of observation.

Before turning to this analysis, we present a general overview of the data on a regime-by-regime basis. We present this evidence in Table 3 which lists cross-country averages and standard deviations of the country-average growth rates and cross-country standard deviations of the key variables used in our analysis as well as for four additional variables, the difference between M2 growth and real GDP growth, a measure of the excess supply of M2, the difference between nominal exchange rate growth and the inflation differential, the rate of growth of the real exchange rate, the rate of growth of the relative excess supply of M2 and the relative rate of inflation. The latter are defined as the difference between the foreign and U.S. variables in both instances.

As it turns out, these figures provide an important first bit of evidence on the performance of theory. They are both fully consistent with the quantity-theory explanation of inflation behavior and, except for certain aspects of exchange-rate behavior, with the closely-related classical neutrality proposition. The average rates of growth of the monetary variables, and in particular excess M2, increase and then decrease across the three periods. The same is true for the other nominal variables. Consistent with the neutrality proposition, the average rates of growth of the two real variables, real GDP and the real exchange rate, in contrast, follow entirely different patterns. In the main, the same things hold for the cross-country standard deviations.

For the average growth rates of nominal exchange rates, there is a parallel with movements in the relative average inflation rate and a lesser but still positive association with relative excess M2 growth.

\footnotetext{
${ }^{8}$ In a considerable number of instances we encountered breaks in these data and in several cases missing observations. Breaks were corrected by interpolation. Publications of the OECD provided most of the missing data.
} 
Even in the case of relative inflation, however, the changes in nominal exchange rate growth are substantially greater, the result of which is a positive association between inflation and real-exchange-rate growth. This departure from neutrality is mirrored in the behavior of the standard deviations. Nominal and real exchange rates behavior is more variable across countries under both post-1973 inflation regimes and although this variability in both instances has decreased somewhat during the third regime the decreases are considerably less than the decreases in the cross-country variability of inflation. The match is, however, somewhat closer with relative M2 growth.

We turn now to the growth shifts. Figures 3 and 4 contain graphs of these data. Tables 4 and 5 report the corresponding regression results. Plotted in three panels of Figure 3 are shifts in the average rates of inflation, nominal GDP, and real GDP in the twenty countries against shifts in the rate of growth of the nominal M2 money stock. Plotted in two panels of Figure 4 are shifts in the average rate of growth of nominal U.S. dollar exchange rates against shifts in the rate of growth of relative consumer prices and shifts in the rate of growth of relative excess supplies of money, again proxied by the difference in the relative rates of growth of money and real GDP. The crosses in each instance indicate growth shifts from period one to period two; the circles, growth shifts from period two to period three.

Taken as a group, the forty points in the consumer-price chart appear fairly evenly dispersed about the forty-five-degree line through the origin. Over the broad range of experience, therefore, the one-to-one relationship between inflation and money growth suggested by theory approximately holds. For nominal GDP, we see very much the same thing. The only difference is the somewhat tighter dispersion of the points about the forty-five-degree line for nominal GDP than for consumer prices. ${ }^{9}$ For real GDP, the picture is markedly different. There clearly is no positive relationship between real GDP and money, only what appears to be a rather weak negative relationship.

The regression results reported at the top of Table 4 are completely consistent with these visual

\footnotetext{
${ }^{9}$ The likely reason for this closer fit, as we point out below, is the effect of shifts in real income on the demand for money.
} 
impressions. The slope coefficients in both the nominal GDP and the consumer price regressions are close in value to and insignificantly different from unity and the intercept in the nominal GDP regression is close to and insignificantly different from zero. Both regressions, moreover, account for a high proportion of the variance of the independent variable - 78 per cent in the case of nominal GDP versus money and 66 per cent in the case of consumer prices versus money. In the real GDP regression, in contrast, the explanatory power of the growth shift in money is quite low and its estimated slope coefficient small in absolute value, findings that again are consistent with theory. The coefficient is, however, negative and significantly different from zero in apparent violation of theory. As it turns out, there is more to this story.

The other noticeable feature of the data plotted in Figure 3 is the difference in the relations between the three key variables and money in the two shift episodes. For both nominal GDP and consumer prices, most of the observations for the first growth shift are above the forty-five-degree line and to the right; most of the observations for the second, in contrast, are below the line and to the left. For real GDP, the bulk of the observations for the first shift appear to be scattered about a horizontal line intersecting the vertical axis several percentage points below the origin while those for the second appear to be scattered about a line intersecting the vertical axis a percentage point or so above the origin. In neither episode, is there any clear association between the shift in real GDP growth and the shift in money growth.

The remaining three regressions in Table 4 focus on these phenomena. In the first of these, we regressed the growth shift in real GDP on the growth shift in nominal money and a dummy variable for the second shift. This variable, DS2, took the value of 1 for the second shift and 0 otherwise. The algebraic sum of its coefficient and the constant is, therefore, an estimator of the mean real GDP shift in the second episode and the constant alone an estimator of the mean shift in the first episode. The coefficient of DS2 was highly significant while the $\mathrm{R}^{2}$ increased from .51 to .73 . The growth shift in nominal money became insignificant. The estimate of the mean shifts were -2.7 per cent and 0.3 per cent, for the first and second episode, respectively. 
The difference in real GDP behavior in these two episodes also explains some of the differences in price behavior. We see this in the fifth regression reported in Table 4. In this regression, we replaced the growth shift in the nominal money stock by the growth shift in the excess supply of money, proxied once again as the difference between the growth shifts in nominal money and real GDP. Using this simple measure of monetary ease and tightness resulted in a marked improvement in goodness of fit - an increase in the $\mathrm{R}^{2}$ of roughly a third. The coefficient of the excess-supply of money variable, moreover, was close to and insignificantly different from unity.

Real income effects, though important, appear to be only part of the explanation for the difference in price behavior since a similar pattern is visible in the chart showing the relation between nominal GDP and money, implicit in which is an allowance for a unit real income elasticity of money demand. To investigate this phenomenon further we ran an additional regression in which we regressed the growth shift in nominal GDP, $\Delta \mathrm{dY}$, on DS2 (and a constant). ${ }^{10}$ Since $\Delta \mathrm{dy} \equiv \Delta \mathrm{dP}-(\Delta \mathrm{dM} 2-\Delta \mathrm{dy})$ this regression in effect imposes both the constraint of a unit income elasticity of demand and the constraint of a one-to-one effect of nominal money on prices. This regression is the last of those reported in Table 4. The coefficient of DS2 in the regression was negative and significant; the constant, positive and significant. The resultant estimates of the mean difference between $\Delta \mathrm{dP}$ and $(\Delta \mathrm{dM} 2-\Delta \mathrm{dY})$ were 2.1 percentage points and -1.3 percentage points respectively.

In both instances, the pattern is of the sort to be expected from theory. A one-time increase in the anticipated rate of inflation and hence in nominal interest rates would lead to a one-time shift in the level of the real money balances demanded. During a period in which a series of such upward shifts in nominal interest rates took place, we, therefore, might expect to see a series of shifts in the level of real money balances demanded and hence a temporary but perhaps protracted effect on their rate of change. During

\footnotetext{
${ }^{10}$ The reason we adopt this simple empirical expedient is because reliable interest rate data are available only for a subset of countries for our full sample period. In any event, given the financial changes that occurred over this period it is by no means clear that a single interest rate such as the treasury bill rate would be an adequate measure of the opportunity cost of holding money were such data available for all of the countries.
} 
the this period, inflation would run systematically higher than the rate of nominal money growth. The reverse would be true during periods in which the anticipated rate of inflation was continually declining. This first set of conditions to a large extent appears to have been characteristic of the 1974-1983 period and the second to the period thereafter.

Additionally there may be an effect of we called the "portmanteau variable"operating. The financial innovations that began in the late 1970s and that continued thereafter, among other things, resulted in a substantial increase both in the range of assets providing monetary services and in the services provided by existing monetary assets. These developments might be expected to have reenforced the effects of the declines in interest rates on the real quantity of money demanded in the third period. The factors that gave rise to these innovations in the 1970s and early 1980s - in particular the existence of deposit interest ceilings as in the United States - very likely reenforced the effects of the increases in interest rates on the quantity of real money balances demanded in the second period. ${ }^{11}$

In the three regressions reported in Table 5, we examine exchange-rate behavior. In both, the shift in nominal U.S. dollar exchange rate growth is the dependent variable; the differentials in inflation shifts and in excess M2 growth alternate as the independent variables. The first two relations are plotted in Figure 4. In the last of the regressions reported in Table 5, the shift in real exchange rate growth is the dependent variable and the shift in the M2 growth differential is the independent variable. The coefficients of both the inflation differential and the excess M2 growth differential are statistically significant, and in the case of the excess M2 growth differential not statistically different from unity. Purchasing power parity in growth rate form continues to work tolerably well as also does the monetary model of exchange rates. Excess M2 growth, in contrast, has no effect on the real exchange rate.

\footnotetext{
${ }^{11}$ The move to ATMs, as an example, has altered the service flow that money holders receive from deposits. In principle, such improvements in the "quality" of those assets could lead either to decreases or increases in the real quantities of deposits that are held in the same way that technical change in the production of conventional goods can either decrease or increase the factors of production that are used to produce those goods. For earlier discussions of these issues see Klein (1974) and Lothian (1976).
} 


\section{Conclusions}

The experience of the United States and other industrial countries during the past four and a half decades with its two sea changes in inflation behavior and the accompanying differences in such behavior among countries is a fertile ground for testing the key propositions of monetary theory. The move to floating exchange rates provided governments with the degree of freedom to pursue divergent and in some instances substantially more expansive monetary policies than under the pegged, but occasionally changing, nominal exchange rates of Bretton Woods. The subsequent declines in inflation throughout the industrialized world added to the richness of this experience.

We use panel data for 20 OECD countries over this period to test two key propositions of monetary theory -- that inflation is a monetary phenomenon, traceable in the first instance to excess growth in money supply and that the nominal exchange rate as the price of two monies moves directly with the relative excess supplies of the two monies.

Using relatively simple techniques, we find strong support for both propositions. We explain both the major temporal movements in inflation and nominal exchange rate growth and the bulk of the differences in the time paths of both among countries. In the main, we also are unable to reject the restrictions placed on the coefficients in these two relationships by the theory. In the process, we also find support for another key tenet of classical monetary theory, the neutrality proposition.

What accounts for the difference between these findings, particularly the difference during the episode of inflation decline, and those reported in much of the existing literature? The answer, we believe, is errors in variables, in the broader senses in which both Estrella and Mishkin (1997) and Friedman and Schwartz (1991) use the term, and the failure of much of the existing research to adjust for these errors. Focusing on the major temporal movements in the data - the cross-regime shifts that are our basic units of observation - is one way of dealing with the signal extraction problem and resultant downward bias in coefficient estimates that such errors produce. Taking cross-country variation into account, as Coakely et 
al. (2002) point out and as we also do here, is another such method. Correspondingly, averaging the data, which is the first step in our analysis, is a traditional approach to the e.i.v. problem.

The implications of this analysis are straightforward. Viewed in a long-run context, the quantity theory model continues to perform tolerably well. The well-documented difficulties of the model in explaining behavior in the short run fade as the time horizon as lengthened and the focus shifted to major movements.

Left unanswered is the deeper question of what accounts for the monetary fluctuations underlying the major movements in inflation in these countries. John Taylor (2002) in his overview of the period considers the various alternatives and concludes that a large part of the initial problem was the intellectual failings of the naive Phillips curve model. ${ }^{12}$ Correspondingly, he attributes the lowering of inflation to changed procedures for conducting monetary policy that are "more rule-like or systematic" and to a "diffusion of ideas and experience about monetary policy" that spurred and otherwise enabled policymakers to implement less-inflationary monetary policy. To paraphrase Richard Weaver, "Ideas had consequences." If Taylor's conjectures are in fact correct, the results reported here become all the more important, serving as an additional reminder of the potential harm that can result from ignoring the longstanding implications of classical monetary theory.

\footnotetext{
12 A similar argument is made by Sargent. Boschen and Weise (2003) present evidence supporting this interpretation. Ireland (1999), presents evidence supporting an alternative time-consistency explanation of policy.
} 


\section{References}

Baillie, Richard T. and Pecchenino, Rowena A. "The Search for Equilibrium Relationships in International Finance: the Case of the Monetary Model." Journal of International Money and Finance, December 1991, 10(4), pp. 582-593.

Bernanke, Ben S. Remarks at the Conference to Honor Milton Friedman, University of Chicago, November 8, 2002. Board of Governors of the Federal Reserve System, http://www.federalreserve.gov/boarddocs/speeches/2002/20021108/default.htm.

Bernanke, Ben S.; Gertler, Mark and Watson, Mark. "Systematic Monetary Policy and the Effects of Oil Price Shocks.” Brookings Papers on Economic Activity, 1997, (1), pp. 91-157.

Blinder, Alan. "The Anatomy of Double-Digit Inflation in the 1970s," in Robert E. Hall, ed., Inflation: Causes and Effects. Chicago: University of Chicago Press, 1982.

Bordo, Michael D. "The Bretton Woods International Monetary System: An Historical Overview," in Michael D. Bordo and Barry Eichengreen, eds., A Retrospective on the Bretton Woods System: Lessons for International Monetary Reform. Chicago: University of Chicago Press for the NBER, 1993.

Borio, Claudio E.V. "Monetary Policy Operating Procedures in Industrial Countries.” Bank for International Settlements Working Paper No. 40, March 1997.

Boschen, John F. and Weise, Charles L., "What Starts Inflation: Evidence from OECD Countries,"Journal of Money, Credit and Banking, June 2002, 35 (3) pp. 323-349.

Carlson, John B.; Hoffman, Dennis, L.; Keen, Benjamin D. and Robert H. "Results of a Study of the Stability of Cointegrating Relations Comprised of Broad Monetary Aggregates." Journal of Monetary Economics, October 2000, 46(2), pp. 345-383.

Coakley, Jerry, Flood, Robert P. and Taylor, Mark P. "Long-Run Relative Purchasing Power Parity: The First Tests," Unpublished working paper, University of Warwick, 2002.

Crowder, William J."The International Convergence of Inflation Rates During Fixed and Floating Exchange Rate Regimes." Journal of International Money and Finance, August 1996,15(4), pp. $551-575$.

Darby, Michael R. "The Price of Oil and World Inflation and Recession." American Economic Review, September 1982, 72(4), pp. 738-751.

Darby, Michael R., Lothian, James R. and Gandolfi, Arthur E., Stockman Alan C. and Schwartz, Anna J. The International Transmission of Inflation. Chicago: University of Chicago Press for the NBER, 1983.

Dewald, William G. "Bond market inflation expectations and longer-term trends in broad monetary growth and inflation in industrial countries, 1880-2001" European Central Bank Working Paper No. 253, September 2003.

. "Historical U.S. Money Growth, Inflation and Inflation Credibility." Federal Reserve Bank of St. Louis Review, November/December 1998, 80(6), pp. 13-23. 
Duck, Nigel W. "Some International Evidence on the Quantity Theory of Money."Money, Credit and Banking, February 1993, 25(1), pp. 1-12.

Dwyer, Gerald P. and Hafer, R.W. "Are Money Growth and Inflation Still Related?" Federal Reserve Bank of Atlanta Economic Review, Second Quarter 1999, 84(2), pp. 32-43.

Estrella, Arturo and Mishkin, Frederic S. "Is there a role for monetary aggregates in the conduct of monetary policy?” Journal of Monetary Economics, October 1997, 40 (2), pp. 279-304.

Fisher, Mark E. and Seater, John J. "Long-run Neutrality and Superneutrality in an ARIMA Framework." American Economic Review, June 1993, 83(3), pp. 402-415.

Flood, Robert P. and Rose, Andrew K. "Fixing Exchange Rates: A Virtual Quest for Fundamentals." Journal of Monetary Economics, August 1995, 36(1), pp. 3-37.

Flood, Robert P. and Taylor, Mark P. "Exchange Rate Economics: What's Wrong with the Conventional Macro Approach?," in Jeffrey A. Frankel, Giampaolo Galli, and Alberto Giovannini, eds. The Microstructure of Foreign Exchange Markets. Chicago: University of Chicago Press for the NBER, 1996.

Friedman, Benjamin M. and Kuttner, Kenneth N. “ Money, Income, Prices, and Interest Rates.” American Economic Review, June 1992, 82 (3), pp. 472-492.

." "A Price Target for U.S. Monetary Policy? Lessons from the Experience with Money Growth Targets." Brookings Papers on Economic Activity, 1996, (1), pp. 77-146.

Friedman, Milton, and Schwartz, Anna J. A Monetary History of the United States, 1867-1960. Princeton: Princeton University Press, 1963.

March 1991, 81(1), pp. 39-49.

Goldberg, Lawrence G.; Lothian, James R. and Okunev, John. "Has International Financial Integration Increased." Open Economies Review, July 2003, 14(3), pp. 299-317.

Hafer, R.W. "What Remains of Monetarism?” Federal Reserve Bank of Atlanta Economic Review, Fourth Quarter 2001, 86(4), pp.13-23.

Hamilton, Earl J. American Treasure and the Price Revolution in Spain, 1501-1650. Cambridge, MA: Harvard University Press, 1934.

International Monetary Fund. International Financial Statistics, various issues and data CD ROM.

Ireland, Peter N. "Does the time-consistency problem explain the behavior of inflation in the United States?” Journal of Monetary Economics, October 1999, 44 (2), pp. 279-291.

Johnson, Harry G. "The Case for Flexible Exchange Rates, 1969." Federal Reserve Bank of St. Louis Review, June 1969, 51(6), pp.12-.22.

Joyce, Joseph P. and Kamas, Linda. "Money and Output under Alternative Exchange Rate Regimes in the 
U.S.” Journal of International Money and Finance, December 1994, 13(6), pp. 679-697.

Klein, Benjamin, "Competitive Interest Payments on Bank Deposits and the Long-Run Demand for Money," American Economic Review, December 1974, 64(6), pp. 931-949.

Lastrapes, William D. and Koray, Faik. "International Transmission of Aggregate Shocks under Fixed and Flexible Exchange Rate Regimes: United Kingdom France and Germany, 1959-1985." Journal of International Money and Finance, December 1990, 9(4), pp.402-423.

Lerner, Eugene M. "Inflation in the Confederacy, 1861-1865," in Milton Friedman, ed., In Studies in the Quantity Theory of Money. Chicago: Chicago University Press, 1956, pp. 163-175.

Lothian, James R. "The Demand for High-powered Money," American Economic Review, March 1976, 66(1), pp. 56-68.

Lothian, James R. "Equilibrium Relationships Between Money and Other Economic Variables." American Economic Review, September 1985, 75(4), pp. 828-835.

."Multi-Country Evidence on the Behavior of Purchasing Power Parity under the Current Float," Journal of International Money and Finance, February 1997, 16(1), pp. 19-36.

Mark, Nelson C. and Sul, Donggyu. "Nominal Exchange Rates and Monetary Fundamentals: Evidence from a Small Post-Bretton Woods Panel." Journal of International Economics, February 2001, 53(1), pp. 29-52.

McCandless, George T. Jr. and Weber, Warren E. "Some Monetary Facts." Federal Reserve Bank of Minneapolis Quarterly Review, Summer 1995, 19(3), pp.14-24.

Meese, Richard and Rogoff, Kenneth. "Empirical Exchange Rate Models of the 1970's: Do They Fit out of Sample?” Journal of International Economics, February 1983, 14(1-2), pp.3-24.

Meltzer, Allan H. "U.S. Policy in the Bretton Woods Era." Federal Reserve Bank of St. Louis Review, May-June 1991, 73(3), pp. 54-83.

Rolnick, Arthur J. and Weber, Warren E. "Money, Inflation, and Output under Fiat and Commodity Standards.” Journal of Political Economy, December 1997, 105(6), pp.1308-1321.

Sargent, Thomas J. The Conquest of American Inflation, Princeton: Princeton University Press, 1999.

Schwartz, Anna J. "Secular Price Change in Historical Perspective." Journal of Money, Credit and Banking, Part 2: The Universities--National Bureau Conference on Secular Inflation, February 1973, 5(1), pp. 243-269.

Taylor, Alan M. "A Century of Purchasing-Power Parity," Review of Economics and Statistics, February 2002, 84 ( 1), pp. 139-150.

Taylor, John B. "A Half-Century of Changes in Monetary Policy.” Written Version of Remarks Delivered at the Conference in Honor of Milton Friedman, University of Chicago, November 8, 2002. 
Wheeler, Mark and Pozo, Susan. "Is the World Economy More Integrated Today than a Century Ago?" Atlantic Economic Journal, June 1997, 25(2), pp. 139-154. 


\section{Table 1a}

$\operatorname{AR}(1)$ for Cross-country average inflation rate

\begin{tabular}{crrrr}
$\mathbf{a v g}\left(\mathbf{d} \mathbf{p}_{\mathbf{t}}\right)=\mathbf{b}_{\mathbf{1}}+\mathbf{b}_{\mathbf{2}} \mathbf{D}_{\mathbf{2}}+\mathbf{b}_{\mathbf{3}} \mathbf{D}_{\mathbf{3}}+\mathbf{b}_{\mathbf{4}} \mathbf{a v g}\left(\mathbf{d p} \mathbf{p}_{\mathbf{t}-\mathbf{1}}\right)$ \\
\hline coefficient & \multicolumn{1}{l}{ std. error } & t-statistic & probability \\
\hline $\mathbf{b}_{\mathbf{1}}$ & 1.262 & 0.482 & 2.620 & 0.013 \\
$\mathbf{b}_{\mathbf{2}}$ & 1.536 & 0.795 & 1.933 & 0.061 \\
$\mathbf{b}_{\mathbf{3}}$ & -2.204 & 0.727 & -3.032 & 0.005 \\
$\mathbf{b}_{\mathbf{4}}$ & 0.762 & 0.093 & 8.152 & 0.000 \\
& & & & \\
$\mathbf{R}^{2}$ & 0.865 & & & \\
SEE & 1.191 & & &
\end{tabular}

F-statistic

Log likelihood ratio
Chow breakpoint test: 19741982

$\begin{array}{rlr}6.145 & \text { probability } & 0.0008 \\ 21.760 & \text { probability } & 0.0002\end{array}$

Note: $\operatorname{avg}\left(\mathrm{dp}_{\mathrm{t}}\right)$ is the cross-country average of the 20 countries' annual inflation rates for 1958 to 1998; D2 takes the value 1 for 1974 to 1998 and 0 otherwise; D3 takes the value 1 for 1982 to 1998 and 0 otherwise. 
Table 1b

AR(1) for Cross-country standard deviation of inflation

\begin{tabular}{crrrr}
\multicolumn{5}{c}{$\mathbf{s d e v}\left(\mathbf{d} \mathbf{p}_{\mathbf{t}}\right)=\mathbf{b}_{\mathbf{1}}+\mathbf{b}_{\mathbf{2}} \mathbf{D}_{\mathbf{2}}+\mathbf{b}_{\mathbf{3}} \mathbf{D}_{\mathbf{3}}+\mathbf{b}_{\mathbf{4}} \mathbf{S d e v}\left(\mathbf{d} \mathbf{p}_{\mathbf{t}-\mathbf{1}}\right)$} \\
\hline coefficient & \multicolumn{2}{l}{ std. error } & t-statistic & probability \\
\hline $\mathbf{b}_{\mathbf{1}}$ & 1.095 & 0.215 & 5.095 & 0.000 \\
$\mathbf{b}_{\mathbf{2}}$ & 1.952 & 0.297 & 6.561 & 0.000 \\
$\mathbf{b}_{\mathbf{3}}$ & -2.009 & 0.300 & -6.687 & 0.000 \\
$\mathbf{b}_{\mathbf{4}}$ & 0.324 & 0.097 & 3.337 & 0.002 \\
& & & & \\
$\mathbf{R}^{2}$ & 0.891 & & & \\
$\mathbf{S E E}$ & 0.473 & & &
\end{tabular}

F-statistic

Log likelihood ratio

\section{Chow breakpoint test: 19741988}

$\begin{array}{lll}16.7698 & \text { probability } & 0.000 \\ 43.5659 & \text { probability } & 0.000\end{array}$

Note: $\operatorname{sdev}\left(\mathrm{dp}_{t}\right)$ is the cross-country standard deviation of the 20 countries' annual average inflation rates for 1958 to 1998; D2 takes the value 1 for 1974 to 1998 and 0 otherwise D3 takes the value 1 for 1988 to 1998 and 0 otherwise. 
Table 2

Estimated Break Points in Inflation Rates in "Floating Rate"

Period Minimum SE for $d p_{t}=b_{1}+b_{2} D_{2}+b_{3} D_{3}+b_{4} d p_{t-1}$

\begin{tabular}{lcc}
\hline & & \\
\hline AUS & Start date for 3rd period & SEE \\
AUT & 1991 & 1.925 \\
BE & 1985 & 1.195 \\
CA & 1984 & 1.383 \\
DE & 1983 & 1.313 \\
FI & 1983 & 1.657 \\
FR & 1982 & 2.378 \\
GE & 1985 & 1.376 \\
IR & 1982 & 1.108 \\
IT & 1984 & 2.205 \\
JA & 1984 & 2.048 \\
NE & 1977 & 2.443 \\
NZ & 1977 & 1.415 \\
NO & 1988 & 2.284 \\
PO & 1988 & 1.956 \\
SP & 1985 & 2.841 \\
SWE & 1979 & 2.362 \\
SWI & 1992 & 1.937 \\
UK & 1992 & 1.570 \\
US & 1981 & 2.396 \\
& 1981 & 1.416 \\
\hline
\end{tabular}


Table 3. Means and standard deviations of cross-country data by periods

\begin{tabular}{lrrr}
\hline & $\mathbf{1 9 5 8 - 7 3}$ & $\mathbf{1 9 7 4 - 8 3}$ & $\mathbf{1 9 8 4 - 9 8}$ \\
\cline { 1 - 1 } & & & \\
\hline Means & & & \\
dH & 4.23 & 10.30 & 3.71 \\
dM2 & 8.00 & 9.51 & 5.01 \\
dM2-dy & 10.76 & 12.23 & 7.35 \\
dy & 5.85 & 10.09 & 4.73 \\
dE & 4.98 & 2.14 & 2.61 \\
dQ & -0.53 & 4.01 & -0.62 \\
relative dP & -1.97 & 1.67 & -1.06 \\
relative dM2-dy & 1.33 & 2.34 & .45 \\
& 2.51 & 2.89 & 2.25
\end{tabular}

\section{$\underline{\text { Standard Deviations }}$}

\begin{tabular}{llll} 
dP & 1.83 & 4.59 & 2.29 \\
dH & 7.23 & 8.47 & 9.35 \\
dM2 & 5.13 & 6.08 & 5.09 \\
dM2-dy & 5.14 & 6.02 & 4.99 \\
dy & 2.65 & 2.07 & 1.87 \\
dE & 2.74 & 7.25 & 5.71 \\
dQ & 3.11 & 5.74 & 5.48 \\
relative dP & 1.83 & 4.65 & 2.34 \\
relative dM2-dy & 4.92 & 6.11 & 5.04 \\
\hline
\end{tabular}

Note: All data are in the form of average annual rates of growth. The symbols $\mathrm{dP}, \mathrm{dH}, \mathrm{dM} 2, \mathrm{dy}, \mathrm{dE}$ and dQ represent the growth rates of the price level, high-powered money (IFS "reserve money"), M2 (IFS "money" plus "quasi-money"), real GDP, the nominal US dollar exchange rate and the real U.S. dollar exchange rate respectively; dM2-dy is a proxy for the growth rate of the excess supply of money; relative $\mathrm{dP}$ and relative dM2-dy are the differences between the respective foreign and U.S. variables. 
Table 4. Results of cross-country regressions for nominal GDP, consumer prices and real GDP

\begin{tabular}{|c|c|c|c|c|c|}
\hline Dependent variable & Constant & $\Delta \mathrm{dM2}$ & $\Delta$ dM2-dy & DS2 & $\overline{\mathbf{R}^{2} / \mathrm{SEE}}$ \\
\hline$\Delta d \mathbf{d Y}$ & $\begin{array}{l}0.263 \\
0.616\end{array}$ & $\begin{array}{r}0.983 \\
11.521 \\
(-.200)\end{array}$ & & & $\begin{array}{l}0.777 \\
2.503\end{array}$ \\
\hline$\Delta \mathbf{d P}$ & $\begin{array}{l}2.072 \\
2.889\end{array}$ & $\begin{array}{r}1.240 \\
8.651 \\
(1.673)\end{array}$ & & & $\begin{array}{r}.663 \\
4.204\end{array}$ \\
\hline$\Delta$ dy & $\begin{array}{l}-1.371 \\
-6.221\end{array}$ & $\begin{array}{l}-0.236 \\
-6.245\end{array}$ & & & $\begin{array}{r}0.506 \\
-0.236\end{array}$ \\
\hline$\Delta \mathbf{d y}$ & $\begin{array}{l}-2.742 \\
-9.192\end{array}$ & $\begin{array}{l}-0.028 \\
-0.587\end{array}$ & & $\begin{array}{l}3.019 \\
8.462\end{array}$ & $\begin{array}{l}0.730 \\
1.039\end{array}$ \\
\hline$\Delta \mathbf{d P}$ & $\begin{array}{l}0.479 \\
1.000\end{array}$ & & $\begin{array}{r}1.107 \\
13.518 \\
(1.303)\end{array}$ & & $\begin{array}{l}0.828 \\
3.006\end{array}$ \\
\hline$\Delta d \mathrm{dP}-(\Delta \mathrm{dM} 2-\mathrm{dy})$ & $\begin{array}{l}2.097 \\
3.697\end{array}$ & & & $\begin{array}{l}-3.379 \\
-4.212\end{array}$ & $\begin{array}{r}.318 \\
2.537\end{array}$ \\
\hline
\end{tabular}

Note: The symbol $\Delta$ represents a first difference operator; thus $\Delta \mathrm{dx}$ is the change in the regimeaverage rate of growth of $\mathrm{x}-$ the growth shift in $\mathrm{x}$. The symbol $\mathrm{dY}$ is the average rate of growth of nominal GDP; all other variables are as defined for Table 3. Conventional t statistics are given directly beneath the coefficient estimates; $t$ statistic to test the hypothesis that the coefficient is unity are given beneath the coefficient in parentheses. 
Table 5. Results of cross-country regressions for exchange rates

\begin{tabular}{|c|c|c|c|c|}
\hline Dependent variable & Constant & Relative dP & Relative $\Delta$ (dM2-dy) & $\mathbf{R}^{2} / \mathrm{SEE}$ \\
\hline$\Delta \mathbf{d E}$ & $\begin{array}{l}0.631 \\
1.110\end{array}$ & $\begin{array}{r}1.356 \\
8.405 \\
(2.206)\end{array}$ & & $\begin{array}{l}0.662 \\
3.467\end{array}$ \\
\hline$\Delta \mathbf{d E}$ & $\begin{array}{l}0.088 \\
2.448\end{array}$ & & $\begin{array}{r}.800 \\
3.429 \\
(-1.085)\end{array}$ & $\begin{array}{l}0.156 \\
5.181\end{array}$ \\
\hline$\Delta \mathrm{dQ}$ & $\begin{array}{l}0.088 \\
0.104\end{array}$ & & $\begin{array}{r}.114 \\
0.687\end{array}$ & $\begin{array}{l}0.013 \\
3.670\end{array}$ \\
\hline
\end{tabular}

Note: All of the underlying variables are as defined in Table 3. The symbol $\Delta$ represents a first difference operator; Relative $\Delta \mathrm{dP}$ and Relative $\Delta(\mathrm{dM} 2-\mathrm{dy})$ are defined with the US as the numeriare. Thus, for example, Relative $\Delta \mathrm{dP}$ for country i, equals $\Delta \mathrm{dP}_{\mathrm{i}}-\Delta \mathrm{dP}_{\mathrm{Us}}$. Conventional t statistics are given directly beneath the coefficient estimates; $t$ statistic to test the hypothesis that the coefficient is unity are given beneath the coefficient in parentheses. 
Figure 1

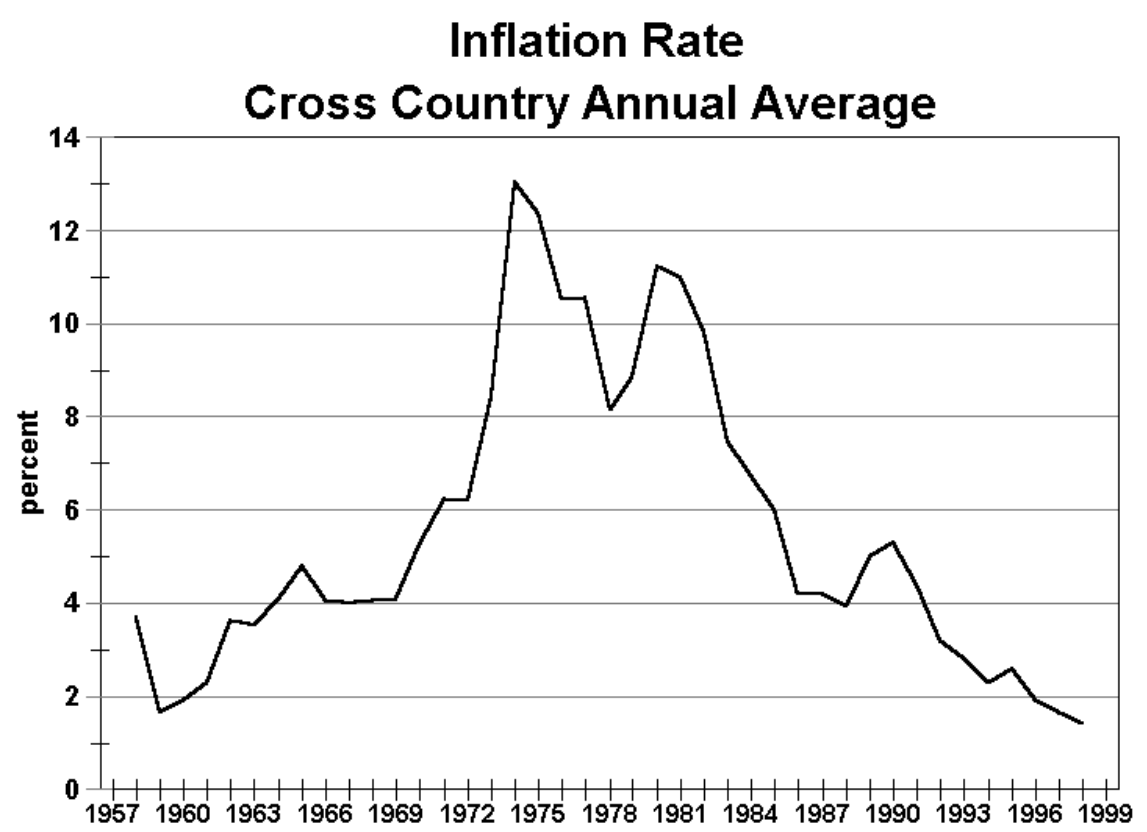

Figure 2

Inflation

Cross Country Standard Deviation

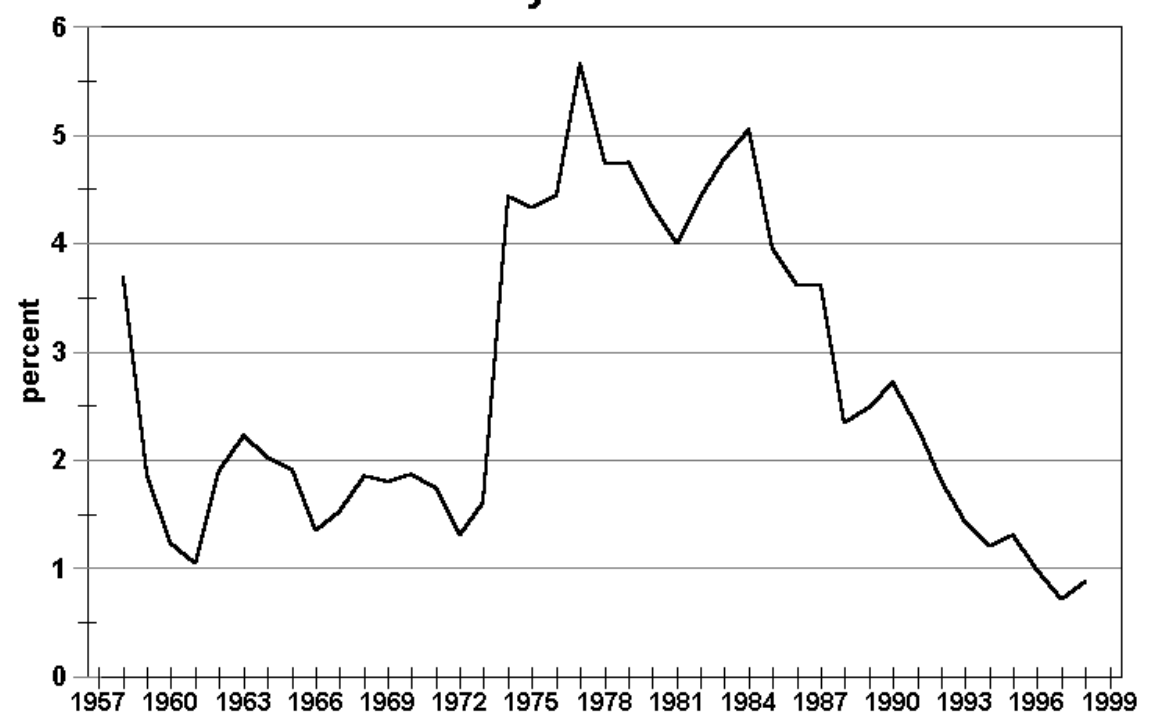


Figure 3. Growth shifts in Nominal GDP, Real GDP and Consumer Prices vs. Growth Shifts in Money Across 20 OECD Countries

3a. Nominal GDP vs. Money

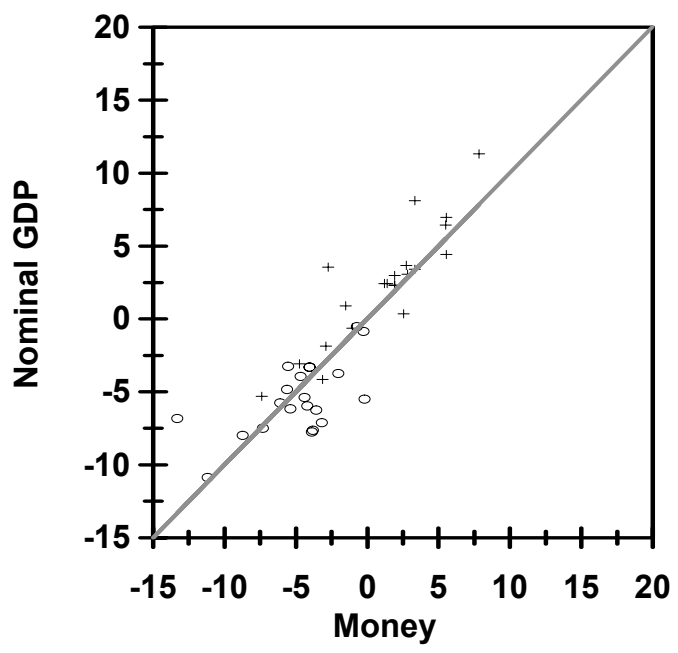

3b. Prices vs. Money

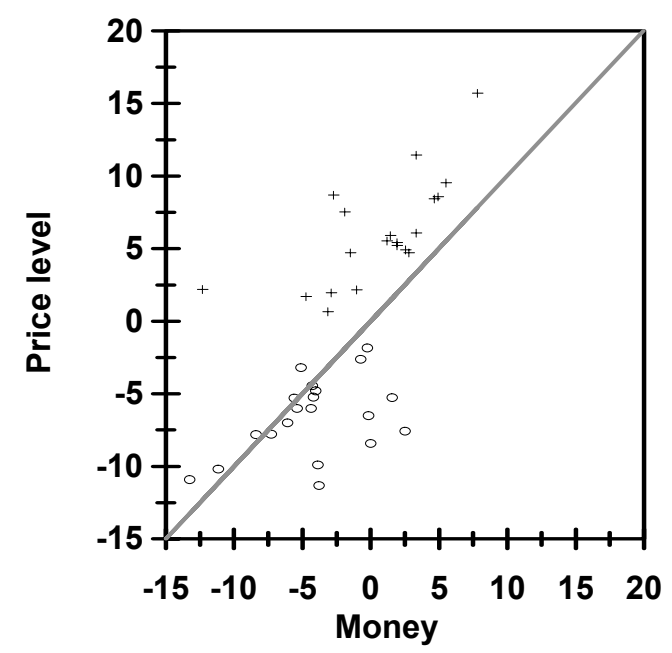


3c. Real GDP vs. Money

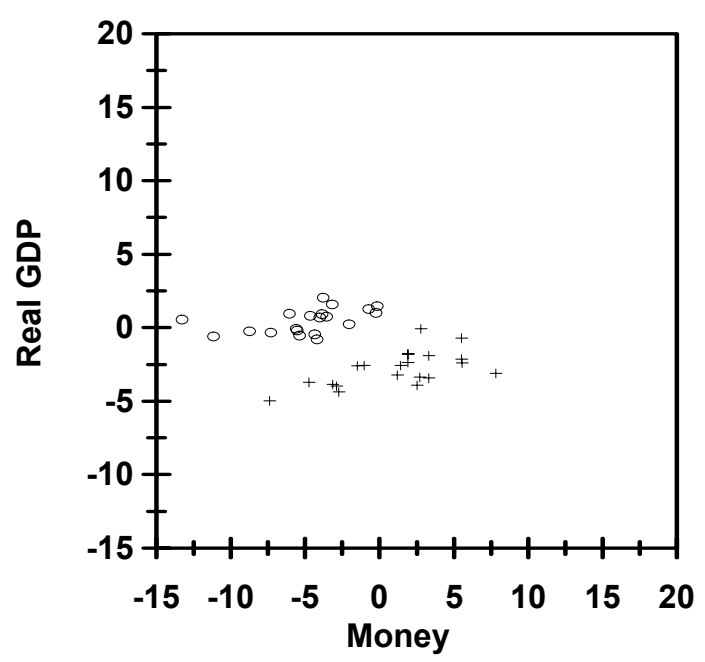


Figure 4. Growth Shifts in Nominal Exchange Rates vs. Relative Prices and Relative Excess Money across 19 OECD Countries

4a. Exchange Rate vs. Relative Prices

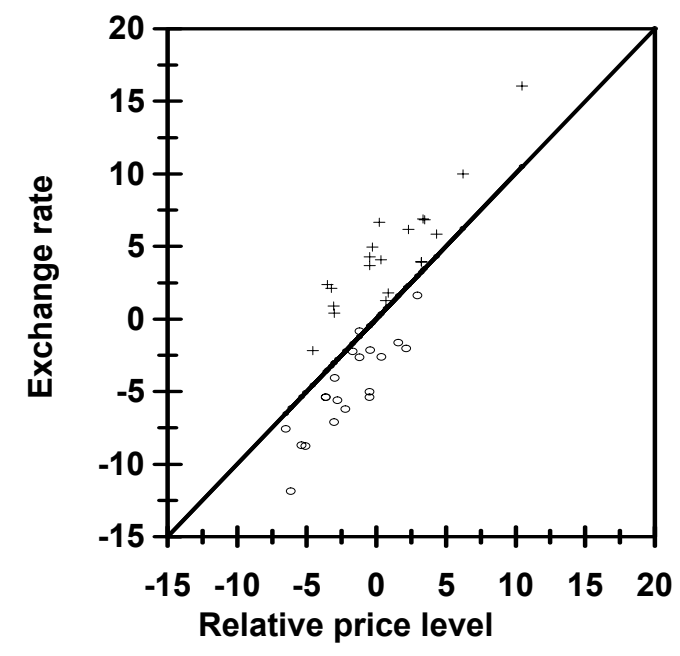

4b. Exchange Rate vs. Relative Excess Money

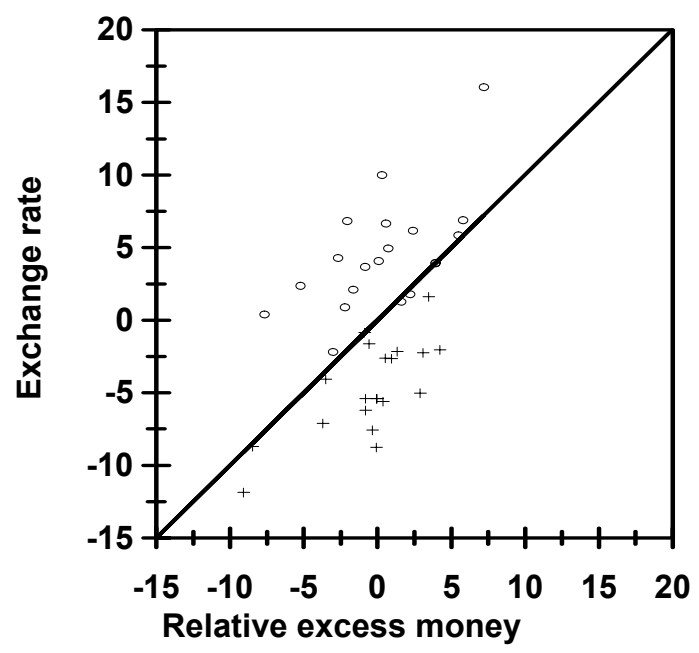

